\title{
EFFECT OF REPLECEMENT CORN GRAINS BY DRIED ORANGE PULP IN DAIRY GOAT RATIONS ON THEIR PRODUCTIVE PERFORMANE
}

\author{
Afaf H. Zedan and A. R. Khattab \\ Animal Production Research Institute, Agriculture Research Center, Dokki, Giza, Egypt.
}

(Received 1/3/2017, accepted 17/4/2017)

\section{SUMMARY}

\begin{abstract}
A feeding trail was conducted to evaluate the effect of replacement corn grains by dried orange pulp (DOP) as source of energy in the concentrate feed mixture of Baladi dairy goats on nutrients digestibilties, feeding value, feed intake, milk yield and composition ,feed efficiency and some parameters of blood. Twenty four Baladi dairy goats within three seasons of lactation, aged $3-4$ years and average weight $28.62 \mathrm{~kg}$ were divided randomly to four similar groups (6 goats each) to receive the experimental rations those contained 0, 50, 75 and 100\% DOP replacing of corn grains in concentrate feed mixtures (FCM) with berseem hay (BH) at 50: 50 to cover the maintenance and production requirements for $\mathrm{R}_{1}, \mathrm{R}_{2}, \mathrm{R} 3$ and $\mathrm{R}_{4}$, respectively. Four digestibility trails were conducted to determine the digestibility and feeding values of the experimental ratios. Results indicated that the experimental rations were almost similar in their nutrients digestibilties, expect CF digestibility which significantly increased by increasing the DOP levels in the rations, also NFE digestibility tended to be significant higher only with 50\% DOP- ration than the control one. The feeding value as TDN was significantly higher for alltested rations than that of control one , but the feeding value of DCP were similar between the lower-DOP ration and that of control one , while the values of the other tested rations were significant lower than that of control one. Inclusion DOP in rations had no significant effect on feed intake. Milk yield and $4 \%$ fat corrected milk yield were different significantly among the dietary treatments being the best milk yield was occurred with $50 \%$ DOP ration. Almost there were no significant differences among the experimental dietary treatments respecting the concentrations of all milk constituents, except milk fat that significantly higher in particular with tasted rations which contained the lower and medium levels of DOP. Also, no significant differences for feed efficiency among the experimental treatments were observed. Most blood parameter values of all dietary treatments were seemed to be similar. Economic efficiency was improved particular with the tested ration that has the lower level of DOP (50\%). It could be concluded that dried orange pulp could be replace at the rate of $50 \%$ of corn grains in dairy goat rations without any adverse effect on productive performance and health of Baladi dairy goats.
\end{abstract}

Key words: Dried orange pulp, replacement, corn grains, digestibility, milk yield, blood, goats.

\section{INTRODUCTION}

In Egypt, the key limiting factor in animal production is considerably due to the high cost of formulating livestock rations along the year as there is a kind of completion between human and livestock for the conventional feedstuffs like corn grains as a main source of energy, therefore it is necessary to being search currently for feed resources that are inexpensive and available and does not directly required as component of human diet and can economically considering as a vital ingredients in the rations of farm animals without adverse effects on the rumen microbial fermentation and performance of the animals (Qelurem et al.,2007).

There are a lot of agro- industrial by- products which could be using potentially to replace corn grains and the other traditional feedstuffs. Dried orange pulp (DOP) or citrus pulp could beusing effectively as an alternative energy source in replacement of some grains as corn, barley and other concentrated ingredients (Gado et al., 2011). The DOP is by- product produced after juice extraction from the orange fruit and then promptly treated by drying process. The dried citrus pulp is a mixture of peel, inside portions and culled fruits of the citrus family (eg., orange ,lemons and gap fruit, etc.) that has been dried to produce a coarse, flakey product (Harris, 1991). Citrus pulp consist of 60-65\% peel, 30-35\% pulp and 0$10 \%$ seeds (Crawshaw,2004) , it contains 90-94\% DM, 93-95\% OM, 6-16\% CP, 12-17.5\% CF,3.2-11.5\% EE, 3.9-7.3\% ash and 55.73- 70.1\% NFE (Osman et el., 2007). The DOP is similar to grains in nutritive 


\section{Zedan and Khattab}

value (80\% TDN) and high in digestible fiber that considerably favorable for rumen functions (Bampidis and Robinson, 2006).

Over year 2014, annual word production of orange was estimated by 50.7 million metric tons, while in Egypt, the annual production was estimated by 2.570 million tons (USDA, 2014). Dried orange pulp has relatively high nutritive value for feeding ruminants and could be considered as one of most cost effective ingredient involved in the diets of farm animals (Nam, 2006). When replaced corn grains by DCP at 0 , 33, 66 and $100 \%$ in goats rations, results showed a quadratic effect on growth performance of growing kids with increasing levels of replacements (Bueno et al., 2002). Dried citrus pulp practically orange pulps have been extensively used in feeding dairy cows (Belibasakis and Tsirgogianni, 1996 and Mohammed, 2015). Furthermore, Omer and Tawila (2009) concluded that sun dried citrus pulp can be replaced yellow corn in goat rations without any adverse effect on gain or rumen fermentation. Also, using this ingredient could be increased the economical efficiency by reducing approximately $25 \%$ of the cost of production.

The aim of this study was to evaluate the effect of partial or total replacement of corn grains by DCP as a source of energy in CFM of Baladi dairy goats on nutrient digestibility feeding value, feed intake, milk yield and composition, feed conversion ratio, economical efficiency and some parameters of blood.

\section{MATERIALS AND METHODS}

The present experiment was carried out at a private dairy goat that located farm in Giza governorate, Egypt, in cooperation with Animal Production Research Institute, Agriculture Research Center, Ministry of Agriculture.

\section{Feeding trial:}

\section{Experimental animals:}

Twenty four dairy Baladi goats (within three seasons of lactation), aged $3-4$ years old and weighed in average $28.62 \mathrm{~kg}$ were divided randomly to four similar experimental groups (6 goats each) for three months of suckling period after the first week of lactation as an experimental period which carried out using randomized complete block design. Goats weighed at the beginning and thereafter at two-week intervals.

\section{Feeds and feeding:}

The dried orange pulp (DOP) was prepared by collection of the orange pulp from Egyptian company for trading and agriculture development in El Abor city and then the entire pulp (seeds and peels) of orange was dried artificially after extraction of juice, then DOP was milled in grinding machine to fine particle size and used with the ingredients in formulating four concentrate feed mixtures. Corn grains were replaced by dried orange pulp in concentrate feed mixture (CFM) at level of $0 \%, 50 \%, 75 \%$ and $100 \%$ in CFM1, CFM2, CFM3 and CFM4, respectively as shown in Table (1). Correspondingly, the experimental rations were consisted of $50 \%$ of berseem hay $(\mathrm{BH})$ plus $50 \%$ CFM1 that served as control ration (R1) or plus CFM2 (R2) or plus CFM3 (R3) or plus CFM4 (R4) as the tested rations of the feeding trial that lasted over three months. All rations were calculated provisionary to cover the nutritional requirements of animals according to NRC (1981) for goat production. Berseem hay was offered twice daily at 8.30 a.m. and 5.30 p.m., while CFM was offered at 10.00 a.m. and 7.0 p.m. Water was available at all times for animals. Chemical composition of corn grains, DOP and BH were analyzed in analytic lab, while CFMs and experimental rations were calculated and presented in Table (2). Intake and refusals of feeds were recorded daily. Milk was hand milked twice daily at 7.00 a.m. and 4 p.m. and milk yield was recorded daily and then mixed proportionally by the evening and morning milking. Samples of milk for each doe were taken once of two week and preserved through the lactation period for chemical analysis

\section{Digestibility trials:}

All animals of each group of feeding trial were taken at the last two weeks of trial to determine the nutrients digestibilties and feeding values of the experimental rations by the method of acid insoluble ash (AIA) as an internal marker according to Van Keulan and Yoang (1977). Fecal samples (approximately $200 \mathrm{~g}$ wet weight) were collected from the rectum for three successive days (at 9.00 a.m. and 5.00 p.m.) and composed for each animal and air dried at $55^{\circ} \mathrm{C}$ for $48 \mathrm{hrs}$. and retained for chemical analysis. The digestion coefficient of nutrients was calculated according to the following formula: 
Digestion coefficient of nutrient $=$

$100-\frac{\% \text { AIA in feed }}{\% \text { AIA in feces }} \times \frac{\% \text { nutrient in feces }}{\% \text { nutrient in feed }} \times 100$

Table (1): Formulation of the experimental concentrate feed mixtures.

\begin{tabular}{lcccc}
\hline Item & \multicolumn{4}{c}{ Concentrate feed mixtures (\%) } \\
\cline { 2 - 4 } & CFM1 & CFM2 & CFM3 & CFM4 \\
\hline Feed ingredients & 40 & 20 & 10 & 0 \\
Corn grains & 0 & 20 & 30 & 40 \\
Dried orange pulp & 5 & 5 & 5 & 5 \\
Soybean meal & 20 & 20 & 20 & 20 \\
UndecorticatedCottonseed meal & 30 & 30 & 30 & 30 \\
Wheat bran & 3 & 3 & 3 & 3 \\
Limestone & 1 & 1 & 1 & 1 \\
NaCl & 1 & 1 & 1 & 1 \\
Minerals and vitamins mix. & & & & \\
\hline
\end{tabular}

CFM1, CFM2, CFM3 and CFM4 (Corn grains were replaced by dried orange pulp at level of $0 \%, 50 \%, 75 \%$ and $100 \%$ ).

\section{Blood sampling:}

On the last day of the experimental period $10 \mathrm{ml}$ of blood were collected from the jugular vein from each animal, then centrifuged at $4000 \mathrm{rpm}$ for 20 minutes. The blood serum was separated into dried glass vials and frozen at $-20^{\circ} \mathrm{C}$ till chemical analysis.

\section{Milk sampling:}

Milk samples were collected during the sulking lactation every two week (twice daily) and analyzed. Fat corrected milk was calculated according to Gaines (1928).

\section{Analytical methods:}

Dried samples of feeds and feces were determined for proximate analysis according to AOAC (2000). Milk samples analyzed for fat, protein, total solid (TS), solid not fat (SNF), and ash\% according to the methods of Ling (1963), lactose was calculated by difference. Blood serum samples were determined the concentrations of total protein (Henry and Todd, 1974), albumin (Doumas and et al., 1971), globulin was calculated by subtract the albumin values from total protein. Creatinine (Henry, 1965), urea (Potton and Crouch, 1977), AST and ALT enzymes (Schmidt and Schmidt, 1963), glucose (Siest et al., 198 and cholesterol (Kostner et al., 1979).

\section{Statistical analysis:}

Data were statistically analyzed as one way using SAS (2001). Duncan's multiple rang test (Duncan, 1955) was used to separate means when the dietary treatments effect was significant. Tested rations (R) assigned as the main factor. The statistical model performed was as follow: $Y_{i k}=\mu+R_{i}+E_{i k}$

Where: $\mathrm{Y}_{\mathrm{ik}}=$ an observation, $\mu=$ Overall mean, $\mathrm{R}_{\mathrm{i}}=$ effect of rations, and $\mathrm{E}_{\mathrm{ik}}=$ random error.

\section{RESULTS AND DISCUSSION}

\section{Chemical composition:}

Data of chemical composition of feedstuffs and rations are presented in Table (2). Dried orange pulp as alternative energy source was approximately comparable in respect of contents of DM, OM, CP, and EE with those of corn grains. While, the contents of CF and ash were higher in DOP than those of corn grains and vice versa with NFE content. 
Table (2): Chemical composition of the feedstuffs, concentrate feed mixtures and experimental rations.

\begin{tabular}{|c|c|c|c|c|c|c|c|}
\hline \multirow[t]{2}{*}{ Item } & \multicolumn{7}{|c|}{ Component, $\%$ on DM basis } \\
\hline & DM & $\mathrm{OM}$ & $\mathrm{CP}$ & $\mathrm{CF}$ & EE & NFE & Ash \\
\hline \multicolumn{8}{|l|}{ Feedstuffs } \\
\hline $\mathrm{BH}$ & 89.32 & 87.62 & 11.68 & 31.47 & 1.53 & 42.94 & 12.38 \\
\hline Corn grains & 88.39 & 98.47 & 9.21 & 2.20 & 4.01 & 83.03 & 1.53 \\
\hline DOP & 88.30 & 94.88 & 8.50 & 11.67 & 4.41 & 70.30 & 5.12 \\
\hline \multicolumn{8}{|c|}{ Concentrate feed mixtures(CFM) } \\
\hline CFM1 (0\%DOP) & 90.33 & 91.45 & 15.69 & 7.70 & 4.79 & 63.27 & 8.55 \\
\hline CFM2 (50\%DOP) & 90.24 & 90.45 & 15.55 & 9.59 & 4.87 & 60.72 & 9.27 \\
\hline CFM3 (75\%DOP) & 90.11 & 90.37 & 15.48 & 10.50 & 4.91 & 59.48 & 9.63 \\
\hline CFM4 (100\%DOP) & 90.03 & 90.01 & 15.40 & 11.50 & 4.95 & 58.16 & 9.99 \\
\hline \multicolumn{8}{|c|}{ Experimental rations } \\
\hline $\mathrm{R} 1(0 \% \mathrm{DOP})$ & 89.83 & 89.54 & 13.69 & 19.59 & 3.17 & 53.11 & 10.47 \\
\hline R2 (50\%DOP) & 89.78 & 89.18 & 13.62 & 20.54 & 3.21 & 51.83 & 10.33 \\
\hline R3 (75\%DOP) & 89.72 & 89.00 & 13.58 & 20.99 & 3.23 & 51.21 & 11.01 \\
\hline R4 (100\%DOP) & 89.68 & 89.82 & 13.54 & 21.49 & 3.25 & 50.55 & 11.19 \\
\hline
\end{tabular}

BH: Berseem hay, DOP: dry orange pulp.

This values are nearly in agreement with those estimated by (Allam et al., 2011 and Mohammed, 2015) who found that chemical composition of DOP were $89.66 \%, 92.51 \%, 8.48 \% 13.85 \%$, $4.66 \%, 65.51 \%$ and $7.45 \%$ for DM,OM, CP,CF,EE, NFE and Ash, respectively. The contents DM and CP for DOP were similar with those recorded in NRC (1981). The four concentrate feed mixtures in the experimental rations were seemed to be in isonitrogenous state and had the same contents of OM, EE and Ash. The tested concentrate feed mixtures (FCM2, FCM3and FCM4) were higher in CFcontent and lower in NFE content in comparison with control one (CFM1). This difference in CF may be due to that DOP containinghigh amount of the neutral detergent soluble fiber fraction that includes pectin compound (250 g pectin/kg DM; as estimated by (Arthington et al., 2002), soluble sugars (120 to $400 \mathrm{~g} / \mathrm{kg} \mathrm{DM}$ ), and less than $10 \mathrm{~g}$ starch/kg DM as recorded by (Volanis et al., 2006). The four experimental rations were contained the same chemical composition except CF\% that increased by increasing the level of DOP in the rations and that may be due to high CF\% in DOP.

Therefore DOP could be favorably used as energy source replacement of some varieties of grains like corn in the diets of ruminant. These are in agreement with the results obtained Gado et al. (2011).

\section{Digestibility and feeding values:}

Digestion coefficients and feeding values of the experimental rations are presented in Table (3). Results indicated that replacement corn grains by different levels of DOP (50, 75 and 100\%) in ratios (R2, $\mathrm{R} 3$, and R4) had not significant effect on all nutrients digestibility coefficients, except those of CF and NFE compared with control ration (R1). The digestibility of CF was significant higher with all tested rations than that of control one. Otherwise, NFE digestibility value was significantly higher only with the low level DOP- ration (R2) than that of control one, being non significant differences the other dietary treatments were found.

These results are in agreement with those obtained by Bampidis and Robinson (2006), Gholizadeh and Naserian. (2010) and Shdaifat et al. ( 2013) who reported that DM and OM digestibilties tend to remain unaffected, CP digestibility decreased and crude fiber fractions (NDF and ADF) digestibility increased when dried citrus pulp substitute for starchy feeds. Also Fegeros et al (1995) stated that, digestibility of $\mathrm{CP}$ in citrus pulp is around $85 \%$ of that in corn. Also on earlier study, Ben-Ghedalia et al. (1989) noticed that CP was more digestible in the starch- rich diet (barely) and NDF was more digestible in the pectin rich diet (dry citrus pulp) in the concentrate diet, while OM equally digested in both diets. In this respect, as a result of the presence of tannin and saponinin in the tested ratios those contain DOP which reduced protein degradation in the rumen so that appreciable quantity of protein was available post-ruminally for highly efficient of enzymatic digestion. This is in agreement with that decided by Nkoku and Evbuomwan (2014) who reported that the presence of tannin and saponin lowers the solubility of proteins entering the abomasum and small intestine for digestion. Recently Gawad et al. (2013) reported that DM, OM and CP 
digestibilties remained unaffected by various levels of dried citrus pulp. Likewise, Mohammed (2015) found that partial substitution of yellow corn grains by different levels of DOP at 25, 50 and 75\% did not affect digestibility of all nutrients, expect NFE with dairy cows ration. In contrast, Macías-Cruz et al. (2010) indicated that the DM, OM, and CP apparent digestibility increased with the inclusion of citrus pulp at $75 \%$ of the diet DM.

Table (3): Effect of replacement corn grains by dried orange pulp in dairy goat rations on nutrients digestion coefficients and feeding values.

\begin{tabular}{|c|c|c|c|c|c|}
\hline \multirow{2}{*}{ Item } & \multicolumn{3}{|c|}{ Experimental rations } & \multirow[b]{2}{*}{$\mathrm{R} 4$} & \multirow{2}{*}{ SE } \\
\hline & $\mathrm{R} 2$ & R2 & R3 & & \\
\hline DM & 60.54 & 60.60 & 60.54 & 60.48 & 0.10 \\
\hline $\mathrm{OM}$ & 64.33 & 64.50 & 64.35 & 64.40 & 0.04 \\
\hline $\mathrm{CP}$ & 61.19 & 60.36 & 60.32 & 60.35 & 0.39 \\
\hline $\mathrm{CF}$ & $53.55^{\mathrm{d}}$ & $56.70^{\mathrm{c}}$ & $59.95^{\mathrm{b}}$ & $61.42^{\mathrm{a}}$ & 0.58 \\
\hline $\mathrm{EE}$ & 65.22 & 65.75 & 65.38 & 64.97 & 1.89 \\
\hline NFE & $70.13^{b}$ & $71.51^{\mathrm{a}}$ & $70.90^{\mathrm{ab}}$ & $70.43^{\mathrm{ab}}$ & 0.36 \\
\hline \multicolumn{6}{|c|}{ Feeding value (\%DM) } \\
\hline TDN & $60.77^{\mathrm{b}}$ & $61.59^{\mathrm{a}}$ & $61.91^{\mathrm{a}}$ & $61.72^{\mathrm{a}}$ & 0.11 \\
\hline DCP & $8.38^{\mathrm{a}}$ & $8.22^{\mathrm{ab}}$ & $8.19^{\mathrm{b}}$ & $8.17^{\mathrm{b}}$ & 0.01 \\
\hline
\end{tabular}

Specifically, CF digestibility was significantly $(\mathrm{P} \leq 0.01)$ increased linearly by increasing level of DOP in the rations. These results are in agreement with those obtained by Bueno et al. (2002) who indicated that digestibilties of NDF and ADF were linearly increased when fed growing goats on concentrate diet contained different levels of DOP (33, 66 and 100\%) in replacing corn grains. Improvement in CF might be due to the high content of Pectin in DOP which is representing the main carbohydrate portion in dried citrus pulp, and thus it is quickly and extensively degraded by ruminal bacteria (Sunvold et al., 1995). Releasing energy for a rapid microbial growth produces lesser lactate and better condition for fiber fermentation, while feeds having high starch concentrations like corn readily fermentable carbohydrates which produce lactate in the rumen leading to drop in $\mathrm{pH}$ value and reduce fiber digestibility (Gholizadeh, and Naserian. 2010). Hernández et.al (2012) indicated that inclusion of dried citrus pulp (DCP) at the level of $30 \%$ in goat rations positively influenced ruminal microbial fermentation and digestion of the rapid soluble carbohydrates of DCP.

It can be noticed that replacement of corn starch by dried orange pulp pectin resulted in a similar utilization of these nutrients. These results are in agreement by Bueno et al. (2002). In contrast Mohammed (2015) found that significant decreasing in NFE digestibility by increasing partial substitution of yellow corn grains by different levels $(0,25,50$ and $100 \%)$.

Regarding the feeding values, there are significant differences for feeding values as TDN\% and $\mathrm{DCP} \%$ among the tested rations versus control one being all tested rations were significantly higher than that of control respecting TDN and DCP items.

\section{Productive performance of Baladi dairy goats}

Data in Table (4) illustrated the effect of partial or total replacement corn grains by DOP in concentrate feed mixtures on productive performance. Inclusion DOP in rations had no significant effect on feed intake of experimental dairy goat, and assertory the DOP had no adverse effect on palatability. These results are in agreement with those demonstrated by Lanaza (1984) when partial or total replacement of corn or barely grains by dried orange pulp or dried lemon pulp in concentrates feed of dairy cattle. Results here are in agreement with those obtained by Omer and Tawila (2009) who noticed that the DMI was unchanged when replace corn by DOP at levels 25 and 50\%, in concentrates of growing goats. Otherwise Bueno et al. (2002) replaced corn by dehydrated citrus pulp at levels 0,33,66 and100\%, in saanen kids goats diets and they were found that feed intake showed a quadratic effect $(\mathrm{P} \leq 0.05)$ with increasing the levels of replacement. 
Table (4): Effect of replacement corn grains by dried orange pulp on productive performance of Baladi dairy goats.

\begin{tabular}{|c|c|c|c|c|c|}
\hline \multirow{2}{*}{ Item } & \multicolumn{4}{|c|}{ Experimental rations } & \multirow{2}{*}{ SE } \\
\hline & R1 & $\mathrm{R} 2$ & R3 & R4 & \\
\hline Live body weight, $\mathrm{Kg}$ & 28.50 & 28.57 & 28.67 & 28.83 & \\
\hline Dry matter intake, $\mathrm{g} / \mathrm{h} / \mathrm{d}$ & 992 & 1029 & 1190 & 1034 & 0.02 \\
\hline Milk yield, g/d & $886.67^{\mathrm{b}}$ & $931.67^{\mathrm{a}}$ & $888.33^{\mathrm{b}}$ & $856.67^{\mathrm{c}}$ & 68.10 \\
\hline $4 \% \mathrm{FCM}, \mathrm{g} / \mathrm{d}$ & $740.85^{\mathrm{bc}}$ & $818.12^{\mathrm{a}}$ & $775.60^{\mathrm{b}}$ & $734.18^{\mathrm{c}}$ & 361.8 \\
\hline \multicolumn{6}{|l|}{ Yields, g/d } \\
\hline Fat & $25.74^{\mathrm{c}}$ & $29.70^{\mathrm{a}}$ & $28.02^{\mathrm{ab}}$ & $26.22^{\mathrm{bc}}$ & 1.13 \\
\hline Protein & 30.87 & 31.16 & 32.20 & 27.56 & 5.13 \\
\hline $\mathrm{TS}$ & $98.60^{\mathrm{ab}}$ & $104.77^{\mathrm{a}}$ & $97.05^{\mathrm{b}}$ & $85.73^{\mathrm{c}}$ & 2.77 \\
\hline \multicolumn{6}{|l|}{ Milk composition, $\%$} \\
\hline Fat & $2.90^{\mathrm{b}}$ & $3.19^{\mathrm{a}}$ & $3.15^{\mathrm{a}}$ & $3.05^{\mathrm{ab}}$ & 0.01 \\
\hline Protein & 3.48 & 3.34 & 3.39 & 3.22 & 0.03 \\
\hline Lactose & 3.72 & 3.69 & 3.72 & 3.74 & 0.001 \\
\hline $\mathrm{TS}$ & $11.12^{\mathrm{a}}$ & $11.24^{\mathrm{a}}$ & $10.92^{\mathrm{a}}$ & $10.01^{\mathrm{b}}$ & 0.11 \\
\hline SNF & $8 . .22^{\mathrm{a}}$ & $8.24^{\mathrm{a}}$ & $8.10^{\mathrm{a}}$ & $6.96^{\mathrm{b}}$ & 0.23 \\
\hline Ash & 0.98 & 1.02 & 1.00 & 1.00 & 0.006 \\
\hline \multicolumn{6}{|l|}{ Feed efficiency } \\
\hline Milk yield/DMI & 0.89 & 0.86 & 0.77 & 0.83 & 0.01 \\
\hline FCM/DMI & 0.75 & 0.75 & 0.67 & 0.71 & 0.01 \\
\hline
\end{tabular}

Concerning productive performance of lactating goats, actual milk yield and $4 \%$ fat corrected milk yield were significantly affected by most dietary treatments, the highest yield that associated with $50 \%$ DOP- ration (R2). These results are in agreement with the findings obtained by Fegeros et al. (1995) who revealed conceited that DOP is a valuable high energy by- product that can partly replace cereal grains in ewes ration without adverse effect on milkyield and composition. Recent study, Valencia (2014) found that when replacing the concentrate (corn grains) with fibrous by product (citrus pulp) in the diet of dairy goats no significant differences were observed for milk production, while milk fat percentage was significantly greater than the un replacing ration. In support to the present results Allam et al. (2011) concluded that corn grains could be replaced by $50 \%$ DOP as alternative energy source in growing lamb rations contained soya bean meal as protein source to reduce the feed cost without negative effect on animal growth performance and health. It is also noteworthy that when fed citrus pulp after ensilaged and supplemented with dry yeast, Shwerab et al. (2010) found that an improvement of nutrients digestibilties, productive performance and economic return of dairy cows. And they added that the ensiling process of citrus pulp potentially more effective in reducing the contained phytonutrients (anti- nutritional factors) to be below than the critical levels and in turn increased the milk production.

Regards to milk constituents and yields, the results indicated that no significant differences among the dietary treatments respecting the most milk constituents, expect fat, total solid and solid not fat (\%). Either milk fat percentage or yield were significantly higher with $50 \%$ or $75 \%$ DOP- rations than those of control one, while both milk protein content and yield did not significantly affected by all dietary treatments. These results are in agreement with those obtained by Belibasakis and Tsirgoyianni (1996) when Partial or total substitution of corn or barley grain by dried orange pulp (DOP) or dried lemon pulp (DLP) in the concentrates that fed to dairy cattle had no negative effects on milk production or the fat content.

No significantly differences among the dietary treatments respecting the feed efficiency as milk yield/ DMI or $4 \%$ FCM/ DMI therefore, the inclusion of DOP in the diet of lactating goats affected positively on their productive performance. In agreement with present results, Omer and Tawila (2009) concluded that replacements of corn grains by citrus by- production in goat ration improved feed efficiency and decreased daily feeding cost and consequently improved relative economical efficiency. Also Allam et al. (2011) found that all rations contented DOP recorded the best feed conversion values in compression with control one with growing lambs.

\section{Blood parameters:}

Blood serum parameters are presented in Table(6) revealed that there were no significant effect due to replacing corn grains by DOP on concentrations of total protein, albumin, globulin, creatinine, liver function 
parameters ( ALT, AST) and total cholesterol, while urea concentration only with the 100\% DOP-ration (R4) compared with value of control ration (R1) significantly increased.

Table (5): Effect of replacement corn grains by dried orange pulp on some blood parameter of Baladi dairy goats.

\begin{tabular}{lccccc}
\hline \multirow{2}{*}{ Item } & \multicolumn{5}{c}{ Experimental rations } \\
\cline { 2 - 5 } & $\mathrm{R} 1$ & $\mathrm{R} 2$ & $\mathrm{R} 3$ & $\mathrm{R} 4$ \\
\hline Total protein, (g/dl) & 7.04 & 7.02 & 7.10 & 7.08 & 0.05 \\
Albumin, (g/dl) & 4.09 & 4.11 & 4.08 & 4.12 & 0.002 \\
Globulin (g/dl) & 2.95 & 2.91 & 3.02 & 2.95 & 0.05 \\
Urea (mg/dl) & $44.11^{\mathrm{b}}$ & $44.13^{\mathrm{b}}$ & $44.51^{\mathrm{ab}}$ & $45.62^{\mathrm{a}}$ & 0.17 \\
Creatinine (mg/dl) & 46.11 & 46.17 & 45.58 & 45.65 & 0.35 \\
ALT (u/l) & 42.33 & 42.51 & 42.59 & 42.49 & 0.70 \\
AST (u/l) & 15.26 & 15.52 & 15.44 & 15.52 & 0.03 \\
Total cholesterol (mg/dl) & 100.31 & 100.63 & 101.30 & 101.02 & 2.12 \\
Glucose (mg/dl) & $65.39^{\mathrm{b}}$ & $66.33^{\mathrm{a}}$ & $64.99^{\mathrm{b}}$ & $64.76^{\mathrm{b}}$ & 0.17 \\
\hline a and b:
\end{tabular}

a and : Means within each row have no similar letter(s) are significantly different $(P \leq 0.01$ and 0.05$)$.

Otherwise glucose concentration was recorded the highest value $(P \leq 0.05)$ in $\mathrm{R} 2$ compared with others rations. All parameters were found to be within normal range as reported by Gholizadeh and Naserian. (2010). Similar results were recognized by Allam et al. (2011) who showed that no significant differences in respect all blood parameters among rations contained different levels of DOP with lambs.

\section{Economic evaluation}

The economic evaluation of dairy baladi goats fed rations containing different levels of DOP are shown in Table (6).

Table (6): Economic analysis of dairy goats fed rations containing different levels of DOP.

\begin{tabular}{lllll}
\hline \multirow{2}{*}{ Item } & \multicolumn{4}{c}{ Experimental rations } \\
\cline { 2 - 5 } & $\mathrm{R} 1$ & $\mathrm{R} 2$ & $\mathrm{R} 3$ & $\mathrm{R} 4$ \\
\hline Total feed intake (g/h/d) & 992 & 1029 & 1190 & 1034 \\
CFM (g/h/d) & 490 & 510 & 590 & 544 \\
$\mathrm{BH}$ (g/h/d) & 502 & 519 & 600 & 490 \\
Daily milk yield (g) & 886.67 & 931.67 & 888.33 & 856.67 \\
Price of total feed intake (LE. h/d) & & & & \\
C FM & 1.92 & 1.81 & 1.98 & 1.83 \\
BH & 1.00 & 1.04 & 1.20 & 0.98 \\
Total & 2.92 & 2.85 & 3.18 & 2.81 \\
Price milk yield(LE. h/d) & 13.30 & 13.98 & 13.32 & 12.85 \\
Net profit (LE./h/d) & 10.38 & 11.13 & 10.14 & 10.04 \\
Economic efficiency (\%) & 3.55 & 3.91 & 3.19 & 3.57 \\
Relative improvement & 100 & 110.15 & 89.86 & 100.56 \\
\hline Total price for feed was calculated according
\end{tabular}

Total price for feeds was calculated according to price of the ingredients in local market (2017), Egypt.

The price of one ton of corn grain 3420 LE., dried orange pulp 1500 LE., soya bean meal 7500, Undecorticated Cottonseed meal 5500LE, Wheat bran 3500 LE, Limestone350 LE, NaCL 1000 LE, Minerals and vitamins mix. 1500, BH 2000 LE and Kg milk was 15 LE.

1- Net profit= price of milk yield LE. - Total feeding cost, $L E$.

2- Economic efficiency, $E E=$ net profit / total feeding cost, $L E$.

3- Relative improvement of the control, assuming that the EE of the control $(R 1)=100$

Goats fed on ration contained 50\% DOP in replacing corn grains had recorded the best economic efficiency compared to rations contained $75 \%$ or $100 \%$ DOP or control one. The lowest value was recorded with the ration contained $75 \%$. The same trend was noticed for the improvement in economic evaluation as result replacement corn grains by dried orange pulp. These results are in agreement with 


\section{Zedan and Khattab}

those obtained by Allam et al (2011) who decided that using dried orange pulp as alternative energy source by $50 \%$ replecment corn grains with soybean meal as a protein source to obtained higher performance with lowest cost of feeding. Also comparable results were obtained by Omer and Tawila (2009) who demonstrated that replacement of corn grains by citrus by-product in goat rations improved ADG, feed efficiency and decreased daily feeding cost and consequently improved economical efficiency.

\section{CONCLUSION}

It could be concluded that inclusion of dried orange pulp at the level of $50 \%$ in concentrate feed mixture in replacing of corn grains where it offered by $50 \%$ as a concentrate portion with $50 \%$ berseem hay as a daily ration for goats and this treatment gave the best productive performance for goats.

\section{REFERENCES}

Allam,S.M.; G.A.Abou-ward; M.A.Tawila; M.A.Ali; .K. Alsayed and S.I. El-Naggar (2011). Nutritional and economical impact of using dried citrus pulp as energy source in growing lams rations. Egyptian J. Nutrition and Feeds. 14(3):337-347.

AOAC (2000). Association of Official Analytical Chemists. Official Methods of Analysis. 17 $7^{\text {th }}$ ed., Gaithersburg, Maryland, USA.

Arthington, D.; W.E. Kunkle and A.M. Martin (2002).Citrus pulp for cattle. Food Anim. Prac. 18, 317326.

Bampidis,V.A. and P. H. Robinson (2006). Citrus by-products as ruminant feeds: a review. Anim. Feed Sci. Technol., 128:175-217.

Belibasakis, N.G. and D. Tsirgogianni (1996). Effects of dried citrus pulp on milk yield, milk composition and blood components of dairy cows. Anim. Feed Sci.Technol., 60:87-92.

Ben- Ghedalia, D. ; E. Yosef ; J .Miron and Y. Est (1989). The effects of starch and pectin -rich diets on quantitative aspects of digestion sheep.Animal Feed Sci. and Technol., 24, 289- 298.

Bueno, E. F.; D. Bianchini; F.F. Leinz and C.F. Rodrigues (2002). Effect of replacing corn with dehydrated citrus pulp in diets of growing kids. Small Rumin. Res., 46(2):179-185.

Crawshaw, R. (2004). Co-product Feeds: Animal Feeds from the Food and Drinks Industries .Nothingham University Press.

Doumas, B.A.; W.A. Wastson and H. G. Biggs (1971). Albumin standards and the measurement of serum albumin with bromo cresol green. Clin. Chem. Acta., 31: 87-90.

Duncan,D. B. (1955). Multiple range and multiple F test. Biomrtrics, 11:1-42.

Fegeros, K. ; G. Zervas; S. Stamouli and E. Apostolaki. (1995). Nutritive value of dried citrus pulp and effect on milk and milk composition of lactating ewes. J. Dairy Sci. 78: 1116-1121.

Gado, H.M.; A.Z.M .Salem and N.E. Borhami (2011). Effect of exogenous enzymes ensiled with orange pulp on digestion, blood metabolites and growth performance in lambs. Anim. Feed Sci. Tech. 165, 131-136.

Gains,W.L (1928). The energy basis of increasing energy milk in dairy cows. University Illinois Agriculture.

Gawad, AA; A.E.M. Mahmoud and Y.H. Al Slibi (2013). Response of Growing Bulls Fed Ration Containing Different Levels of Citrus Pulp. World Appl. Sci. J. 28(10):1475-1480.

Gholizadeh, H. and A.A. Naserian (2010). The effects of replacing dried citrus pulp with barley grain on the performance of Iranian saanen kids. J. Anim. And Vet. Adv.,15: 2053-2056.

Harris, B.(1991).Value of high fiber alternative feedstuffs as extenders of roughage sources. Proceedings of the Alternative Feeds for Dairy and Beef cattle Symposium1991, Columbia.Pp138. 
Henry,R.J.(1965). Creatinine and creatine, in Clinical Chemistry Principals and Techniques, New York, Hoeber Medical (Harper \& Row), pp 287-302.

Henry, J. B. and S. D. Todd (1974). Clinical diagnosis and measurement by laboratory methods, $16^{\text {th }}$ Ed., W. B. Saaunders and Co., Phliadephia., Pp 260.

Hernández1, J.; F.Vázquez1; O.D. Montañez and F.A.ucero (2012). Influence of different levels of dried citrus pulp on in vitro ruminal fermentation kinetics of total mixed ration in goat rumen inocula. Journal of Animal and Feed Sciences, 21, 458-467.

Kostner G.M., P. Avogaro , G.B. Bon , G. Cazzolato and G.B. Quinci (1979). Determination of highdensity lipoproteins: screening methods compared. 25, 6:939-42.

Lanza, A. (1984). Dried citrus pulp in animal feeding. In: Holl'o, J. (Ed.), Proceedings of the International Symposium on Food Industries and the Environment. Budapest, Hungary. Elsevier Pulishers, New York, NY, USA, pp.189-198.

Ling, E.R. (1963). A Text Book of Dairy Chemistry.3rd Ed. Chapman and Hall Ltd., London.

Macías-Cruz, U. ; J.A. Quintero-EliseaAvendaño-Reyes; L., Correa-Calderón, Álvarez-Valenzuela; F.D., Soto-Navarro; S.A. Lucero-Magaña and F.A. González-Reyna (2010). Buffel grass (CenchrusciliarisL.) substitution for orange pulp on intake, digestibility, and performance of hair sheep lambs. Trop. Anim. Health Prod. 42, 223-232.

Mohammed, H. M. B. (2015). Partial substitution of yellow corn grains by dried orange pulp in Holstein dairy cow rations. Ph.D. Thesis Faculty of Agri. Cairo University, Egypt.

Nam, I.S (2006). Supplementation of essential oil extracted from citrus peel to animal feeds decreases microbial activity and aflatoxin contamination without disrupting invitro ruminal fermentation. AsianAust.J.AnimSci .19(11):1617-1622.

Nkoku, V. I. and B. O.E. Vbuomwan (2014). Utilization of essential oil and pectin extracted from Nigerian orange peels. Greener Journal of Chemical Science and Technology, 1(1): $1-5$.

NRC (1981). Nutrient Requirements of Domestic Animals. Nutrient requirements of goats. National Research Council, Washington, D.C. USA.

Omer, H.A.A. and M.A. Tawila (2009). Response of Baladi goats to diets containing different levels of citurs by product. Egypt. J. Nutr. and Feeds, 12(1): 75- 88.

Osman,A.A. ; E. S. Soliman; F.Z. Swidanand A.N. Ismail (2007). Evaluation of different rations of citrus and some crop residues silage. Egyptian J. Nutrition and Feeds, 10(2)231-243.

SAS (2001). Statistical Analysis System. User's Guide Version 8.2, Cary NC. USA.

Schmidt, E. and F.W. Schmidt (1963). Determination of serum GOT and GPT.Enzym. Biol. Clin. 3:1.

Shdaifat,M.M.; F.S. Al-Baraka.; A.Q. Kanana, and B.S. Obeidatb (2013). The effect of feeding agricultural by-products on performance of lactating Awass ewe. Small Ruminan Research.113:1114.

Shwerab, A.M.; M.S. Khalel; A.A. Hassan and A.Z. Salem (2010). Influnce of inocalants treatment of citurs pulp and dry yeast supplementation on phytonutrients concentrations, rumen fermermentation and cow performance. Egypt. J. Nutr. and Feeds, 13 (3): 465- 484.

Siest,G. ; J. Henry and F. Schiele (1981). Interpretation des examens de examenydelaborotoirekargered. 206.

Sunvold, G.D.; H.S. Hussein; G.C. Fahey; N.R. Merchen and G.A. Reinhart (1995). In vitro fermentation of cellulose, beet pulp, citrus pulp, and citrus pectin using fecal inoculum from cats, dogs, horses, humans, and pigs and ruminal fluid from cattle. J. Anim. Sci. 73, 3639-3648.

Potton C. J. and S. R.Crouch (1977). Spectrophotometric and kinetics investigation of the bertha lotreoction for the determination of ammonia. Anal. Chem., 49:464-469.

Qelurem ,O.I. ; A.G. Ngi and I.A. Andrew (2007). Phtonutrients in citrus fruit peel meal and nutritional implaction for livectock production. LRRD.eprints. Kfupm, edu.sa/ view /year/ 2007.htmi.

USDA (2014). United States Department of Agriculture.. Citrus: World Markets and Trade . Available at:http://apps.fas.usda.gov/psdonline/circulars/citrus.pdf. 


\section{Zedan and Khattab}

Valencia (2014). Use of dry citrus pulp or soybean hulls as a replacement for corn grain in energy and nitrogen partitioning, methane emissions, and milk performance in lactating Murciano-Granadina goats. J. Dairy Sc., 97 (12)231-243.

Van Keulen, J. and B. A. Young (1977). Evaluation of acid-insoluble ash as a nature marker in ruminant digestibility studies. J. Anim. Sci., 44:282.

Volanis, M.; P. Zoiopoulos.; E.Panagou and C.T zerakis (2006). Utilization of an ensiled citrus pulp mixture in the feeding of lactating dairy ewes. Small Ruminant Res., 64, 190-195.

تاثير احلال حبوب الذرة بمخلف عصير البرتقال الجاف فى علائق الماعز الحلابة على الاداء الانتاجى

$$
\text { معه بحوث حسن زيدان و أحمد رجب خطاب الحيواني - مركز البحوث الزراعية - الدقي - الجيزة - مصر. }
$$

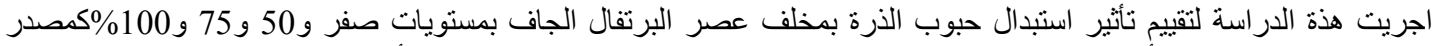

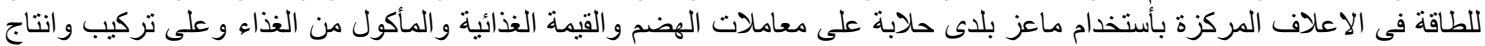

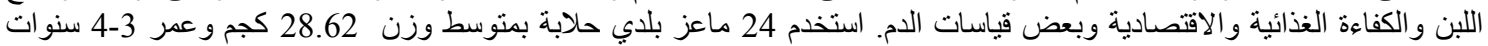

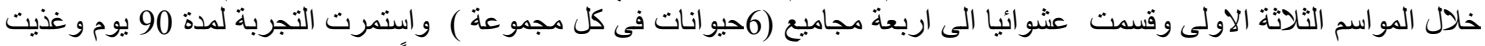

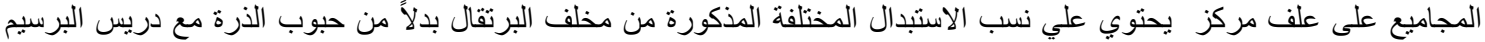

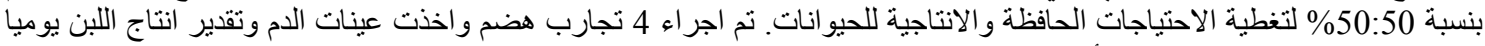

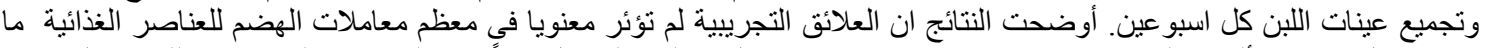

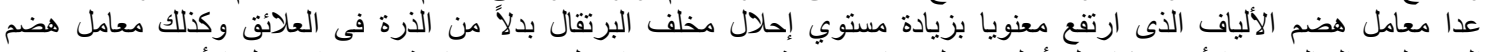

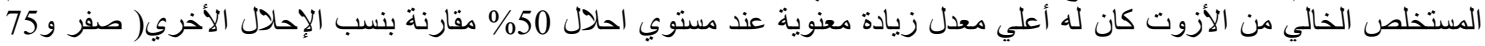

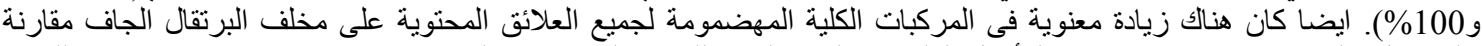

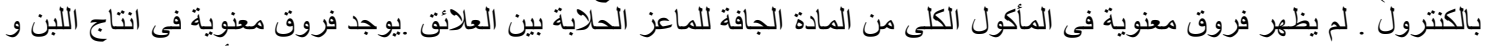

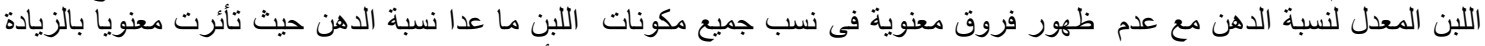

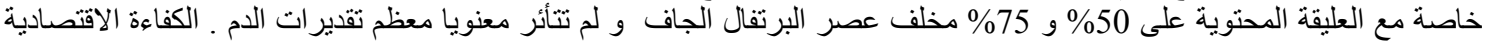

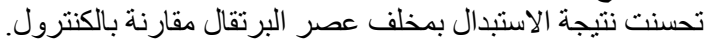
من ذللك نستنتج أن مخلف عصر البرتقال ممكن استبدالة بنسب 50\% بدلأ من حبوب الذرة فى العلائق بدون تأثير سلبى على الأداء

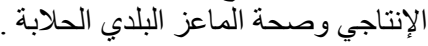

